\title{
Validitas Modul Sistem Koloid Berbasis Inkuiri Terbimbing
}

\author{
A Rahmayati', Iryani ${ }^{1 *}$ \\ ${ }^{1}$ Pendidikan Kimia, Universitas Negeri Padang, Jl. Prof. Dr. Hamka Air Tawar Barat, \\ Padang Utara, Sumatera Barat 25171, Indonesia \\ *iryaniachmad62@gmail.com
}

\begin{abstract}
The Curriculum 2013 requires teacher to carry out teaching-learning process using the scientific approach, so that it can encourage students to be more active individually or in groups. The Colloid system is a chemical material that is studied in the XI class of high school / even semester. This study aims to produce a colloidal system module guided inquiry-based equipped with HOTS questions, and to develop a valid module. The type of research used is Research and Development (R\&D). The development model used is the Ploomp development model which consists of 3 stages that are preliminary research, prototype stage and assesment. The instrument of data collection used is the instrument of validity. The research data was analyzed using the Cohen Kappa formula. The module was validated by 5 validators. The results of the questionnaire analysis of validity by the validator were 0.90 with a very high validity category.
\end{abstract}

\section{Pendahuluan}

Kimia merupakan bagian dari ilmu pengetahuan alam yang mempelajari tentang komposisi, sifat-sifat dan transformasi materi serta bagaimana komposisi suatu materi mempengaruhi sifat-sifatnya [1]. Dalam mempelajari kimia sebagian besar topik-topik pembahasannya bersifat abstrak. Yang maksudnya adalah tidak semua topik pembahasan tersebut bisa diamati langsung oleh panca indera (makroskopik) dan secara simbolik saja, akan tetapi perlu pemahaman mengenai sub-mikroskopik yaitu struktur dan proses pada level partikel (atom/molekul) terhadap fenomena makroskopik yang diamati.

Salah satu materi pembelajaran kimia yaitu sistem koloid. Materi ini merupakan salah satu materi pokok pada kelas XI SMA yang diajarkan pada semester genap dengan alokasi waktu 3 x 4 jam pelajaran [2]. Materi sistem koloid merupakan materi yang banyak mengandung fakta, konsep, prosedur serta teoritis dan hafalan yang harus dikuasi oleh siswa.

Kurikulum 2013 menuntut guru melaksanakan pembelajaran dengan menggunakan pendekatan saintifik, sehingga dapat mendorong siswa lebih aktif secara individu maupun kelompok dalam pembelajaran. Berdasarkan hasil wawancara dengan 3 orang guru kimia (SMAN 3 Padang, SMAN 7 Padang dan SMAN 8 Padang) dan sekitar 20 siswa, diketahui bahwa ketiga sekolah tersebut sudah menerapkan kurikulum 2013. Dan bahan ajar yang digunakan berupa buku cetak dan LKS. Kurikulum 2013 menuntut siswa untuk aktif mencari, mengolah dan mengkonstruksi dalam proses pembelajaran [3].

Salah satu model pembelajaran yang mendukung siswa untuk menemukan konsep sendiri serta sesuai dengan tuntutan kurikulum 2013 yaitu strategi pembelajaran inkuiri terbimbing. Kegiatan belajar yang menerapkan inkuiri terbimbing terdiri dari 5 tahap yaitu orientasi, eksplorasi, pembentukan konsep, aplikasi dan penutup [4]. Model pembelajaran inkuri terbimbing relevan dengan psikologis peserta didik sekolah menengah, karena dalam proses penemuan konsep perserta didik masih tetap mendapat bimbingan dan panduan guru melalui pertanyaan kunci pada tahap pembentukan konsep selama proses pembelajaran [5].

Penelitian sebelumnya yang terkait dengan pengembangan bahan ajar berbasis inkuiri terbimbing pada materi sistem koloid telah dilakukan oleh Nur Afni (2017). Nur Afni telah menghasilkan bahan ajar yang dilengkapi dengan penyajian secara multipel representasi yaitu level submikroskopik, simbolik, 
dan makroskopik yang valid dan praktis serta dapat dipahami oleh siswa. Bahan ajar yang dikembangkan belum dilengkapi dengan soal-soal tipe HOTS (Higher Order Thinking Skills) pada tahapan aplikasi atau lembaran kerja maupun evaluasi dan belum diintegrasikan dengan pendidikan Al-Qur'an. Berdasarkan taksonomi Bloom, proses kognitif terbagi menjadi kemampuan berpikir tingkat rendah (Lower Order Thinking) dan kemampuan berpikir tingkat tinggi (Higher Order Thinking). Menurut Anderson \& Krathwohl, kemampuan yang termasuk LOT adalah kemampuan mengingat (remember), memahami (understand), dan menerapkan (apply), sedangkan HOT meliputi kemampuan menganalisis (analyze), mengevaluasi (evaluate), dan mencipta (create) [12]. Menurut Brookhart kemampuan berpikir tingkat tinggi (HOTS) adalah (1) berpikir tingkat tinggi berada pada bagian atas taksonomi kognitif Bloom, (2) tujuan pengajaran di balik taksonomi kognitif yang dapat membekali peserta didik untuk melakukan transfer pengetahuan, (3) mampu berpikir artinya peserta didik mampu menerapkan pengetahuan dan keterampilan yang mereka kembangkan selama belajar pada konteks yang baru [12].Adanya soal-soal tersebut ditujukan untuk melatih dan mengembangkan pola pikir siswa serta dapat membantu siswa dalam memecahkan berbagai permasalahan yang dihadapi diberbagai situasi [6]. Pendidikan Al-Qur'an dan Budaya Alam Minangkabau pada kurikulum tahun 2006 merupakan mata pelajaran muatan lokal. Seiring dengan perkembangan Kurikulum tahun 2013, mata pelajaran muatan lokal tersebut sejalan dengan pengembangan kompetensi religius dan sosial ( KI 1 dan KI 2 ), sebagai penguatan pendidikan karakter. Maka oleh sebab itu, Dinas Pendidikan Provinsi Sumatera Barat memprogramkan kegiatan pengintegrasian nilai-nilai pendidikan Al-Qur'an dan Budaya Alam Minangkabau pada Kompetensi Dasar (KD) mata pelajaran yang relevan di SMA/SMK. Dengan demikian guru mata pelajaran diharapkan mengelola pembelajaran dengan mengintegrasikan ayat-ayat Al-Qur'an dan Hadis serta nilai-nilai Budaya Alam Minangkabau pada materi yang relevan, dengan harapan melalui pembelajaran guru dapat menginternalisasikan nilai-nilai baik pada peserta didik yang disertai dengan tauladan dari guru. Bagi daerah tertentu Pendidikan Al-Qur'an dapat desesuaikan dengan kitab suci yang relevan, sesuai dengan agama yang dianut [11].

\section{Metode}

Jenis penelitian yang digunakan adalah penelitian pengembangan atau Research and Development (R\&D). Model pengembangan yang digunakan dalam penelitian ini adalah model pengembangan Plomp yang terdiri dari 3 tahapan yaitu penelitian awal (preliminary research), tahap pembentukan prototipe (prototyping stage), dan tahap penilaian (assesment phase) [7]. Subjek penelitian ini terdiri dari 2 orang dosen kimia FMIPA UNP dan 3 orang guru kimia.

Pada tahap penelitian awal (prelimenary research) dilakukan analisis kebutuhan, analisis konteks, studi literatur dan analisis konsep. Analisis kebutuhan dilakukan dengan mewawancarai guru kimia dan siswa untuk mengetahui bagaimana guru serta siswa melaksanakan pembelajaran sistem koloid terutama yang berkaitan dengan bahan ajar. Analisis konteks dilakukan dengan menganalisis kompetensi dasar (KD) 3.14 dan 4.14, berdasarkan KD dapat dirumuskan indikator pembelajaran pada materi sistem koloid. Studi literatur dilakukan untuk mencari dan memahami sumber-sumber yang terkait dengan kegiatan pengembangan. Analisis konsep dilakukan dengan mengidintefikasi, merinci dan menyusun konsep-konsep utama pada materi sistem koloid.

Tahap pembentukan prototipe merupakan tahap perancangan yang diikuti dengan merealisasikan produk berupa modul. Kegiatan yang dilakukan pada tahap pembentukan prototipe sebagai berikut: (a) prototipe I dilakukan dengan merancang modul sistem koloid berbasis inkuri terbimbing. (b) Prototipe II dilakukan evaluasi formatif berupa evaluasi diri sendiri (self evaluation). (c) Prototipe III dilakukan evaluasi formatif berupa uji coba satu satu (one to one) dan penilaian ahli (expert review). Pada penilaian ahli (expert review) dilakukan uji validititas modul yang dikembangkan oleh 5 validator. (d) Prototipe IV dilakukan melalui uji coba kelompok kecil (small group).

Tahap penilaian dilakukan proses uji coba lapangan (field test). Uji coba lapangan ditujukan pada guru dan peserta didik yang ditujukan untuk praktikalitas modul. Hasil uji coba ini digunakan untuk menyempurnakan modul yang telah disusun.

Instrumen pengumpulan data yang digunakan pada penelitian ini yaitu instrumen validitas dan praktikalitas. Instrumen validitas digunakan untuk menilai modul sistem koloid berbasis inkuiri terbimbing yang dilengkapi soal-soal tipe HOTS yang dikembangkan. Instrumen validasi ini ditujukan 
kepada 2 orang dosen kimia FMIPA UNP dan 3 orang guru kimia. Instrumen praktikalitas digunakan untuk mengetahui tingkat praktikalitas pemakaian modul sistem koloid berbasis inkuiri terbimbing yang dilengkapi soal-soal tipe HOTS yang dikembangkan. Instrumen praktikalitas ini ditujukan kepada 2 orang guru kimia dan peserta didik.

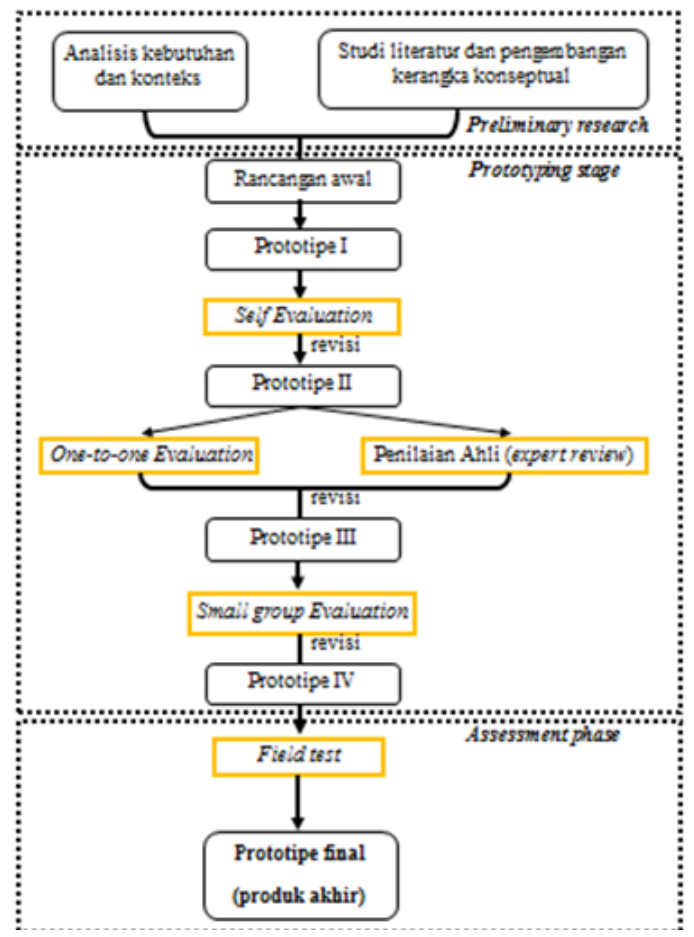

Gambar 1. Langkah-langkah pengembangan modul

Namun penelitian ini hanya dilakukan sampai tahap validasi atau pembentukan prototipe III yaitu melalui uji ahli (expert review). Validitas modul ditentukan dengan menggunakan lembar angket penilaian yang telah divalidasi oleh 5 validator yaitu 3 orang dosen kimia FMIPA UNP dan 2 orang guru kimia SMAN 7 Padang.

Penilaian yang diberikan oleh validator terhadap modul meliputi segi kelayakan isi, kelayakan komponen penyajian, komponen kebahasaan, dan komponen kegrafisan. Data yang diperoleh kemudian dianalisis menggunakan formula Kappa Cohen:

$$
\text { momen kappa }(k)=\frac{\rho_{0}-\rho_{\varepsilon}}{1-\rho_{\varepsilon}}
$$

Keterangan:

\begin{tabular}{l|l|l}
$\mathrm{K}$ & $=$ & momen kappa yang menunjukkan validitas produk \\
\hline$\rho_{0}$ & $=$ & $\begin{array}{l}\text { Proporsi yang terealisasi, dihitung dengan cara jumlah nilai yang diberi oleh validator } \\
\text { dibagi jumlah nilai maksimal }\end{array}$ \\
$\rho_{e}$ & $=$ & $\begin{array}{l}\text { Proporsi yang tidak terealisasi, dihitung dengan cara jumlah nilai maksimal dikurangi den- } \\
\text { gan jumlah nilai total yang diberi validator dibagi jumlah nilai maksimal }\end{array}$
\end{tabular}

Tabel 1. Kategori Keputusan berdasarkan Momen Kappa [8]

\begin{tabular}{c|c} 
Interval & Kategori \\
\hline $0,81-1,00$ & Sangat tinggi \\
\hline $0,61-0,80$ & Tinggi \\
\hline $0,41-0,60$ & Sedang \\
\hline $0,21-0,40$ & Rendah \\
\hline $0,01-0,20$ & Sangat rendah \\
\hline 0,00 & Tidak valid
\end{tabular}




\section{Hasil dan Diskusi}

\subsection{Tahap penelitian awal (preliminery research)}

3.1.1. Analisis Kebutuhan. Melalui observasi yang telah dilakukan di beberapa sekolah diketahui bahwa belum tersedia bahan ajar yang sesuai dengan tuntutan Kurikulum 2013 disekolah, khususnya modul. Diharapkan dengan dikembangkannya modul sistem koloid berbasis inkuiri trbimbing yang dilengkapi soal-soal tipe HOTS dapat mengaktifkan siswa dalam pembelajaran.

3.1.2. Analisis konteks. Pada tahap analisis silabus tahap yang dilakukan adalah menganalisis kompetensi dasar (KD). Kompetensi Dasar materi sistem koloid Berdasarkan kurikulum 2013 revisi sebagai berikut:

3.14 Mengelompokkan berbagai tipe sistem koloid, dan menjelaskan kegunaan koloid dalam kehidupan berdasarkan sifat-sifatnya.

4.14 Membuat makanan atau produk lain yang berupa koloid atau melibatkan prinsip koloid. berikut:

Indikator Pencapaian Kompetensi (IPK) dapat diturunkan berdasarkan KD diatas adalah sebagai

3.14.1 Menelaah perbedaan larutan, koloid dan suspensi

3.14.2 Mengelompokkan jenis koloid berdasarkan fase terdispersi dan medium pendispersi

3.14.3 Membedakan koloid liofol dan koloid liofob

3.14.4 Menjelaskan sifat-sifat koloid (optik, kinetik, listrik, adsorpsi, koagulasi dan dialisis)

3.14.5 Menjelaskan proses pembuatan koloid di laboratorium

3.14.6 Menganalisis peranan koloid dalam kehidupan sehari-hari

4.14.1 Melakukan proses pembuatan koloid dalam kehidupan sehari-hari

3.1.3. Pengembangan kerangka konseptual. Tahap pengembangan kerangka konseptual dilakukan dengan cara mengidentifikasi, merinci, dan menyusun konsep-konsep utama pada materi sistem koloid. Berdasarkan hasil analisis konsep yang telah dilakukan, diperoleh hasil bahwa konsep utama yang harus dikuasai oleh peserta didik antara lain: campuran, campuran homogen, campuran heterogen, koloid, suspensi, larutan, koloid liofob dan liofil, koloid hidrofil dan hidrofob, fase terdispersi, fase pendispersi, sol, emulsi, aerosol, buih, efek Tyndall, gerak Brown, adsorpsi, dialisis, elektroforesis dan koagulasi.

\subsection{Tahap pembentukan prototipe (prototyping stage)}

3.2.1. Prototype I. Prototype I merupakan hasil dari perancangan yang direalisasikan menjadi suatu produk sehingga diperoleh bahan ajar modul sistem koloid berbasis inkuiri terbimbing yang dilengkapi soal-soal tipe HOTS. Prototipe I terdiri dari petunjuk penggunaan modul, rumusan tujuan pembelajaran yang spesifik, lembaran kegiatan, lembaran kerja, lembaran evaluasi, kunci lembaran kerja, kunci lembaran evaluasi [9]. Adapun bentuk rancangan modul yang dikembangkan dapat dilihat pada Gambar 2 . 


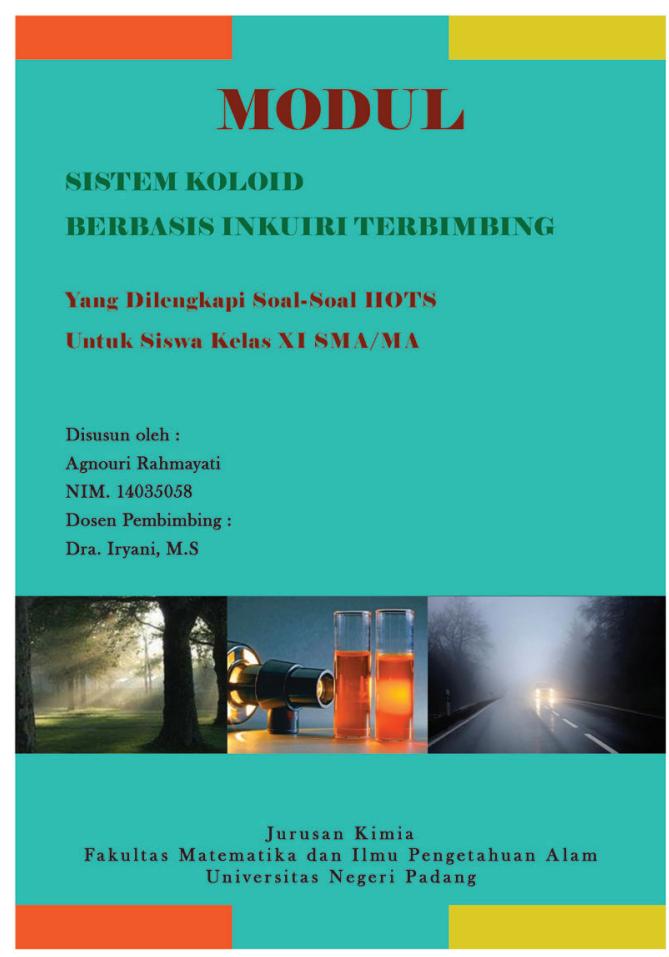

(a)

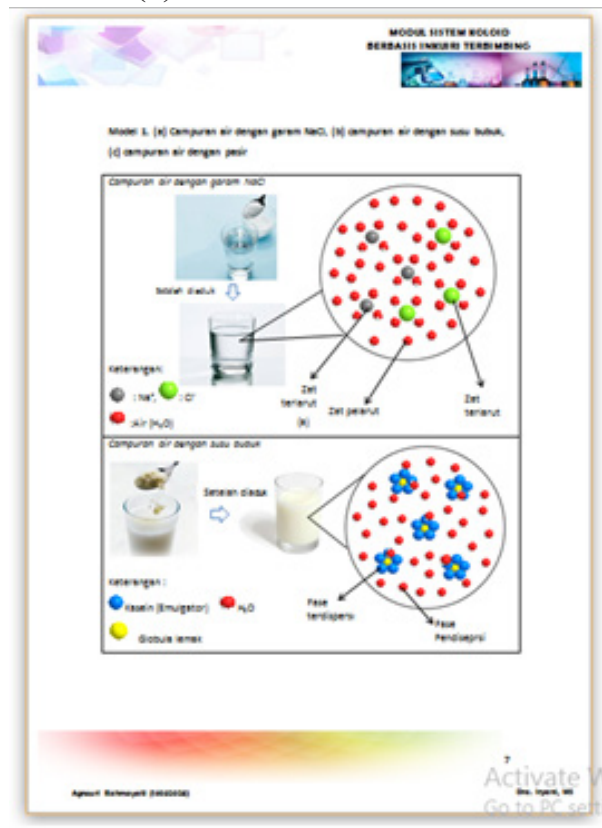

(c)

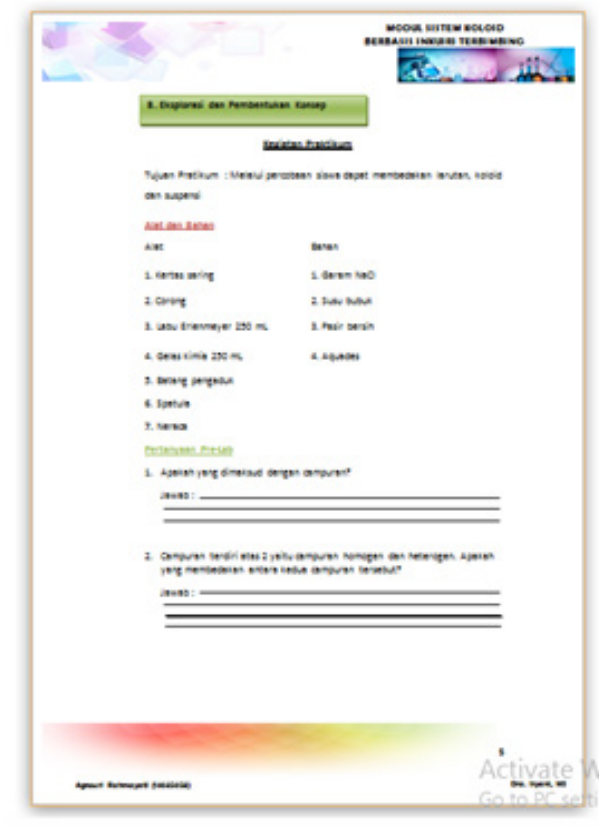

(b)

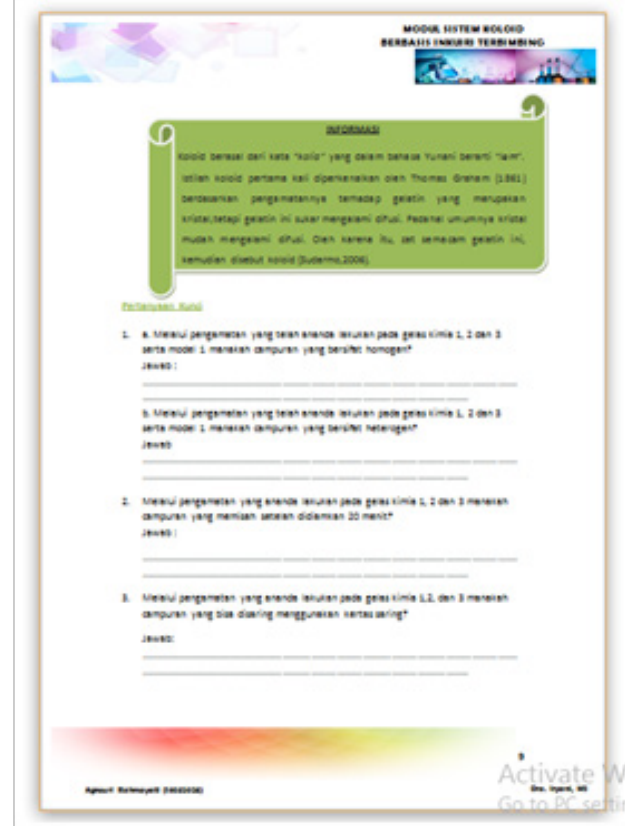

(d)

Gambar 2. Bentuk rancangan modul yang dikembangkan (a)Cover; (b)(c) dan (d) Lembar Kegiatan

3.2.2. Prototype II. Pada tahap ini dilakukan evaluasi formatif berupa evaluasi diri sendiri (self evaluation). Hal yang dilakukan adalah melihat kesalahan seperti penggunaan gambar, pertanyaan kunci dan kelengkapan komponen yang harus ada didalam modul. Jika terdapat bagian yang kurang dilakukan revisi dan menghasilkan prototipe II yang telah direvisi.

3.2.3. Prototype III. Pada tahap ini dilakukan evaluasi formatif berupa penilaian para ahli (expert review) dan uji coba satu-satu (one to one evaluation) pada prototype II. Uji validitas merupakan penilaian terhadap rancangan suatu produk. Penliaian dibagi menjadi beberapa komponen yang terdiri dari kelayakan isi, kelayakan konstruksi, komponen kebahasaan dan komponen kegrafisan. Validasi 
dilakukan oleh 2 orang dosen kimia FMIPA UNP dan 3 orang guru kimia. Dari hasil validasi yang dilakukan oleh beberapa validator dilakukan beberapa perbaikan yaitu: (1) memperbaiki gambar supaya lebih jelas, (2) warna yang terdapat pada cover modul supaya lebih dicerahkan, (3) tata letak judul pada cover diperbaiki, (4) perbaiki pertanyaan kunci, (5) dan perbaiki tata letak/layout. Sehingga akhirnya diperoleh data validasi pada tabel 2.

Tabel 2. Hasil Analisis Data Validitas Oleh Validator

\begin{tabular}{c|c|c} 
Aspek yang dinilai & $\mathbf{K}$ & Kategori Kevalidan \\
\hline Kelayakan isi & 0,87 & Sangat tinggi \\
\hline Kelayakan konstruksi & 0,88 & Sangat tinggi \\
\hline Komponen kebahasaan & 0,94 & Sangat tinggi \\
\hline Komponen kegrafisan & 0,91 & Sangat tinggi \\
\hline Rata- rata & 0,9 & Sangat tinggi
\end{tabular}

Keterangan: $\mathrm{K}=$ momen kappa

Berdasarkan hasil analisis pada Tabel 2, kelayakan isi modul sistem koloid berbasis inkuiri terbimbing yang dilengkapi soal-soal HOTS memiliki nilai momen kappa sebesar 0,87 dengan kategori kevalidan sangat tinggi. Data ini menunjukkan bahwa materi, indikator dan tujuan pembelajaran yang disajikan sudah sesuai dengan tuntutan kurikulum yang digunakan. Materi prasyarat yang disajikan berhubungan dengan materi yang diajarkan. Tahap pembentukan konsep dapat menuntun siswa dalam menjawab pertanyaan kunci berdasarkan model yang diberikan. Tahap aplikasi yang berisi lembaran kerja dapat memantapkan pemahaman peserta didik. Dan tahap penutup pada modul dapat menuntun peserta didik untuk memberikan kesimpulan berdasarkan hasil penyelidikan.

Penilaian kelayakan konstruksi (komponen penyajian) merupakan penilaian yang dilakukan unntuk menunjukkan komponen yang terdapat didalam modul. Berdasarkan hasil analisis data pada Tabel 2 menunjukkan komponen penyajian pada modul memiliki nilai momen kappa sebesar 0,88 dengan kategori kevalidan sangat tinggi. Hal ini menunjukkan bahwa modul yang disusun sudah sistematis mulai dari petunjuk pengguanaan modul, lembar kegiatan, lembar kerja, lembar evaluasi, kunci lembar kerja dan kunci evaluasi. Aktivitas kelas yang disusun pada modul sudah berdasarkan siklus pembelajaran inkuiri terbimbing menurut Hanson yaitu dimulai dari orientasi, ekslporasi, pembentukan konsep, aplikasi dan penutup. Dan pertanyaan kunci yang dibuat sudah sistematis mulai dari pertanyaan sederhana sampai kompleks.

Komponen kebahasaan memiliki nilai momen kappa sebesar 0,94 dengan kategori kevalidan sangat tinggi. Hal ini menunjukkan bahwa bahasa yang digunkan pada modul sudah menggunakan kaidah bahasa indonesia yang baik dan benar. Bahasa yang digunakan juga jelas dan mudah dimengerti serta konsisten dalam menggunakan simbol/lambang. Modul hendaknya memenuhi kaidah user friendly (mudah digunakan). Setiap instruksi dan paparan informasi yang tampil bersifat membantu dan bersahabat dengan pemakainya, termasuk kemudahan pemakai dalam merespon dan mengakses sesuai keinginan [10].

Komponen kegrafisan memiliki nilai momen kappa sebesar 0,91 dengan tingkat kevalidan sangat tinggi. Hal ini membuktikan bahwa jenis ukuran huruf yang digunakan tepat dan jelas dibaca. Gambar pada model juga dapat diamati dengan jelas dan warna yang digunakan sesuai dengan warna yang sebenarnya. Serta desain modul (cover dan gambar) yang dikembangkan secara keseluruhan sudah menarik.

Berdasarkan hasil analisis data validitas oleh validator pada Tabel 2 terlihat bahwa secara keseluruhan penilaian pada komponen kelayakan isi, kelayakan konstruksi, komponen kebahasaan, serta komponen kegrafisan memiliki rata-rata momen kappa sebesar 0,90. Data ini menunjukkan bahwa modul sistem koloid berbasis inkuiri terbimbing yang dilengkapi soal-soal tipe HOTS yang dikembangkan memiliki kategori kevalidan sangat tinggi.

\section{Simpulan}

Berdasarkan penelitian yang telah dilakukan dapat disimpulkan bahwa modul sistem koloid berbasis inkuri terbimbing yang dilengkapi soal-soal tipe HOTS memiliki tingkat kevalidan sangat tingi. 


\section{Referensi}

[1] Brady, J. E., Neil. D. J, Alison H. 2010. Chemistry The Molecular Nature of Matter. USA: John Willey and Sons, Inc.

[2] Peraturan Menteri Pendidikan dan Kebudayaan Republik Indoesia Nomor 22 Tahun 2016 tentang Standar Proses Pendidikan Dasar dan Menengah

[3] Kemendikbud,2013. Kerangka Dasar Kuirkulum 2013. Kementrian Pendidikan dan Kebudayaan Direktorat Jenderal Pendidikan Dasar. Jakarta

[4] Hanson, David. M. (2005). Designing Process-Oriented Guided-Inquiry Activities. In Faculty Guidedbook: A Comprehensive Tool For Improving Faculty Performance, ed. S. W. Beyerlein and D. K. Apple. Lisle, IL: Pacific Crest.

[5] Abidin, Yunus. 2014. Desain Sistem Pembelajaran dalam Konteks Kurikulum 2013. Bandung: Refika Aditama.

[6] Liliasari. 2001. "Model Pengembangan IPA untuk Meningkatkan Keterampilan Berpikir Tingkat Tinggi Calon Guru sebagai Kecenderungan Baru pada Era Globalisasi." Jurnal Pengajaran MIPA UPI (Vol. 2 No.1).

[7] Plomp, Tjeerd. 2007. "Educational Design Research: An Introduction", dalam An Introduction to Educational Research. Enschede, Netherland: NationalInstitute for Curriculum Development

[8] Boslaugh, Sarah dan Paul A. W. (2008). Statistics in a Nutshell, a desktop quick reference. Beijing, Cambridge, Famham, Köln, Sebastopol, Taipei,Tokyo: O'reilly

[9] Suryosubroto,B. 1983. Sistem Pengajaran dengan Modul. Yogyakarta : Bina Aksara

[10] Depdiknas. 2008. Pengembangan Bahan Ajar. Jakarta: Departemen Pendidikan Nasional, Direktorat Jenderal Manajemen Pendidikan Dasar dan Menengah, Direktorat Pembinaan Sekolah Menengah Atas.

[11] Dinas Pendidikan Sumatera Barat. 2017. Pengintegrasian Pendidikan Al Qur'an Dan Budaya Alam Minang Kabau Pada Mata Pelajaran Kimia Sekolah Menengah Atas (SMA). Padang: Dinas Pendidikan Provinsi Sumatera Barat.

[12] Istiyono, Edi, djemari Mardapi, \& Suparno. 2014. "Pengembangan Tes Kemampuan Berpikir Tingkat Tinggi Fisika (PysTHOTS) Peserta Didik SMA.” Jurnal Penelitian dan Evaluasi Pendidikan 18(1). Hlm. 2-3. 